Creative Commons User License: CC BY-NC-ND

Abstracted by: EBSCOhost, Electronic Journals Service (EJS),

Google Scholar, Journal Seek, Scientific Commons,

Food and Agricultural Organization (FAO), CABI and Scopus
Journal of Agricultural Extension

Vol. 23 (1) January, 2019

ISSN(e): 24086851; ISSN(Print); 1119944X

http://journal.aesonnigeria.org

http://www.ajol.info/index.php/iae

Email: editorinchief@aesonnigeria.org

\title{
Technological Changes in Farming among the Tiv Farming Households in Nigeria
}

https://dx.doi.org/10.4314/jae.v23i1.1

\section{Ivande Pauline D.}

Department of Home Science and Management, University of Agriculture, Makurdi, Benue State, Nigeria

Email:ivandepd@yahoo.com

Phone: +2348035059007

\section{Olaolu Michael 0.}

Department of Agriculture, Alex Ekwueme Federal University, Ndufu Alike, Ikwo, Ebonyi State,

Nigeria

Emial: michealolaolu@yahoo.com

Phone: +2348065489702

\section{Igbokwe Edwin M.}

Department of Agricultural Extension, University of Nigeria, Nsukka, Enugu State

Email: edwin.igbokwe@unn.edu.ng

Phone: +2348034261915

\section{Abstract}

This study determined the changes in farming technologies among Tiv farmers. The study used the survey design, with the aid of interview schedule. The study was conducted among the Tiv in Benue, Nassarawa and Taraba States Nigeria which also constituted the population of the study. A multistage sampling procedure was employed to select farming households. A total of 315 farming household were sampled for the study. Data were analysed using frequency, percentages, mean statistics, percentage change and independent sample t-test statistics. There was significant change in frequency of use of innovation/technologies at $P \leq 0.05$ in the colonial and post-colonial periods. Farming tools had a percentage changed of -99.4 on the use of planting stick and 4331.8 for the use of tractor and accessories, while processing machine had a percentage change of 1256.9. There were more farmers who sourced planting material in the post-colonial as compared with the colonial period from Agricultural Development Projects, (ADPs) and input markets had greater increase as sources of across most of the crops studied. The study recommends that state governments should support as many intervention programmes much as required and needed by farmers.

Keywords: Colonial era, Post-Colonial, Tiv farming households Innovations; Technological change

\section{Introduction}

The expansion of modern agriculture in the world through a combination of intensification and extensification has managed to sustain the world population explosion that began with 
the industrial revolution and accelerated in the early to mid-twentieth century (United Nations, 2015). More than $70 \%$ of the Nigerian population is dependent on agriculture for food supply and other livelihoods, and the sector contributes up to $40 \%$ of the country's GDP (Chike and Okpara, 2012 in Ivande 2014). These contributions have changed over the years with changes in the way and manner farming is practised. It is believed that changes in the way thing are done has every link with the culture and tradition of the people (Mbagwe, 2015). The traditions and customs of the communities manifested in their way of living and organization of their operations socially, economically, and even politically. Social organizations, institutions and the use of traditional technologies played very key roles in the course of the development of the economies (agriculture) of rural communities prior to the advent of western science and technology(Mbagwe, 2015). However, in the course of contacts with neighbours, colonialism and other social interrelations, agricultural skills and technologies emerged and small holder farm communities were persuaded to abandon their traditional agricultural practices for modern practices and technologies.

The communities were said to have passed through a phase in development that could lead to social and technological change. According to Mbagwe (2015), the idea of change and continuity shows through available evidence that change, growth or development is intrinsic to any group or society whether traditional or modern. However, these changes may be facilitated and nourished by external agencies. Changes should therefore be viewed as belonging naturally or drawn from within and outside that society. According Mondal (2015), for changes to occur in one part of society, there must be adjustments in other parts. If this does not occur, the society's equilibrium will be disturbed and strain will occur. The process of social change can therefore be thought of as a 'moving equilibrium'. Parsons views social change as a process of 'social evolution' from simple to more complex form of society (Mondal, 2015). Social evolution involves a process of social differentiation. As the parts of society become more and more specialised and distinct, it increases the problem of integration of parts which in turn set forth the process of social change and social equilibrium.

Technological change is a loose concept that has multiple meanings. The concept originates in the 1930s from issues concerning unemployment due to technology. This refers simply to new ways of doing known jobs or even the application of new ways in the execution of a job known to be impossible in order to solve a problem (Benoît, 2015). Its roles include the development of tools that permit the specialization of labour on a gradation of level; which can be demonstrated in the mechanization of agriculture, development of new forms of energy and the mass productions of goods (Ivande, 2014).

To a large extent, the style or method used in managing an organization at any given time reflects the general level of development of the society in which that organization operates. Expectedly, as a society experiences economic, socio-political, infrastructural and other progress, the organizations existing within it improve or grow by way of capacity, 
performance and general efficiency. Similarly, significant societal conditions usually exert some impact on the attitude and behaviour of people at the workplace. It is in this way that the systematic usurpation of the sovereignty of the various peoples living in the west, east and north of the River Niger by the British during the 19th century; ultimately culminating in the colonization of the entire area, came to influence, condition and pattern the political, economic and social systems of the eventual Nigerian state. Colonialism has arguably therefore informed the fundamental culture of modern Nigerian organizations - especially in the way they are organised and operated, and also how the human elements within such settings behave in the process of achieving organizational objectives.

The colonial era began in earnest in the late 19th century, when Britain consolidated its rule over Nigeria. In 1914, the British merged northern and southern protectorates into a single state called the colony and protectorate of Nigeria. Nigeria became independent of British Rule in 1960. Prior to external contacts and intervention programmes/projects the agricultural performance of the pre-colonial Tiv people, found mostly in the States of Benue, Taraba and Nasarawa, indicated that the activities that led to production were part of the duties that formed complex network of rights and obligations which were the kinship, family and sometimes religious and political structures (Bohannan and Bohannan, 1968 in Ivande, 2014). The interactions with external or other cultures could bring about changes in the ways and practices of doing things among different people. These changes could be positive while in other cases could be negative, also, these changes could also lead to the loss of culture and practices of the receiving people. Some of these changes could also be as a result of the persons and the way they went about introducing the innovations, on the other hand, changes could result from the perception of the people being introduced to the innovation. This is because perception will usually affect attitude, and attitude will affect practice. Therefore, the extent the colonial contact changed the Tiv farming technologies becomes very pertinent to ascertain changes that have occurred over time.

\section{Purpose of the study}

The overall purpose of the study was to determine the influence of colonialism on the farming technologies of Tiv farmers, specifically the study sought to:

1. assess the farming technological changes among Tiv farming households;

2. ascertain changes in farm tools used for agriculture among the Tiv in the Colonial and Post-colonial periods; and

\section{Methodology}

3. examine the sources of planting materials among Tiv households.

The study was conducted among the Tiv community of Benue, Nasarawa and Taraba States, Nigeria. The population of the study comprises all the farm families in Benue, Taraba and Nasarawa States. Multi-stage sampling procedure was employed to select farm families. Two agricultural zones predominantly populated by the Tiv, namely, zones $\mathrm{A}$ and $B$ in Benue and one each i Nasarawa and Taraba were purposively selected. Three blocks 
Creative Commons User License: CC BY-NC-ND

Abstracted by: EBSCOhost, Electronic Journals Service (EJS),

Google Scholar, Journal Seek, Scientific Commons,

Food and Agricultural Organization (FAO), CABI and Scopus
Journal of Agricultural Extension

Vol. 23 (1) January, 2019

ISSN(e): 24086851; ISSN(Print); 1119944X

http://journal.aesonnigeria.org

http://www.ajol.info/index.php/iae

Email: editorinchief@aesonnigeria.org

http://eoi.citefactor.org/10.11226/v23i1

from zone A, two from B in Benue State and one each from southern zones of Nasarawa and Taraba were purposively selected giving a total of seven blocks. Three cells/villages were purposively selected from each block giving a total of 21 cells/villages. For the purpose of focus group discussion, one cell/ village each outside the sampled 21 cells/ villages was also selected from the blocks. From the list of farm families from each of the cells/villages, 15 farm families of ages of 50years and above were purposively selected giving a sample size of 315 farm families. This selection was to ensure that all the 15 heads of farm families who were interviewed were not younger than 50yrs and had many years of farming experience enough to enable the extrapolation of agricultural systems of the colonial Tiv. The study period spanned from colonial period (1900-1960) to post-colonial period (1961-2012).

Data for the study were collected through the use of structured interview schedule and FGD. The interview schedule was divided into different sections on the basis of the objectives. Data were analysed using frequency, percentages, mean statistics, percentage change and independent sample t-test statistics.

\section{Results and Discussion}

\section{Socio-Economic Characteristics of Respondents}

The socio-economic characteristics of the respondents are presented in Table 1. The average age of the respondents was 59.8 years. This is derived from the purposive sampling of heads of households over 50 years. There were nearly equal proportions of males $(51.7 \%)$ and females (48.3\%). Most (84.8\%) of the sample was married and $15.2 \%$ was widowed. About $41.0 \%$ of the sample had no formal education with mean years spent in school being 5.2 years. However, when aggregated, many had primary (29.8\%), secondary $(22.2 \%)$ or tertiary $(7.0 \%)$ education. This result implies that the people in this area were not only in a state of being able to transmit and acquire the socially approved aspects of cultural heritage but also could ensure the acquisition of continuous knowledge and stimulates discovery as well as the extension of knowledge because of their age and stay in their location long enough (Soni, 2012).

The majority (44.1\%) had resided in the study area for $51-60$ years with a mean of 56 years for the sample. This implies a wealth of experience and the ability to account for changes in agriculture in the study area. Mean household size was 8.0 persons with a majority (63.5\%) having 1-7 persons. An earlier study reported a mean household size of 11 persons (BNARDA, 2004). This reduction in household size could be attributed to the influence of the family planning programme being intensified to prevent the spread of HIV/AIDS infections and other related health problems in the area. Ministry of Women Affairs and Social Development Benue State (MOWASDBS) (2008) reported that, to improve the quality of life of the people, the Federal Government of Nigeria has announced the removal of user fees for contraceptives which gives people access to free family planning services in all public health facilities.

The majority (68.7\%) had $31-50$ years of farming experience. The mean years of farm experience was 36.8 years. This indicates that most of the respondents have had long standing experience in farming and were in a better position to observe changes in agriculture among the Tiv. 
Creative Commons User License: CC BY-NC-ND

Abstracted by: EBSCOhost, Electronic Journals Service (EJS),

Google Scholar, Journal Seek, Scientific Commons,

Food and Agricultural Organization (FAO), CABI and Scopus

http://eoi.citefactor.org/10.11226/v23i1
Journal of Agricultural Extension

Vol. 23 (1) January, 2019

ISSN(e): 24086851; ISSN(Print); 1119944X

http://journal.aesonnigeria.org

http://www.ajol.info/index.php/jae

Email: editorinchief@aesonnigeria.org

Table 1: Socio-economic characteristics

\begin{tabular}{lll}
\hline Socio-Economic characteristics & $\begin{array}{l}\text { Percentages } \\
(\%)\end{array}$ & Mean $(\bar{x})$ \\
\hline Gender & & \\
Male & 51.7 & \\
Female & 48.3 & \\
Age (years) & & \\
$50-59$ & 48.3 & \\
$60-69$ & 48.6 & \\
$70-79$ & 3.2 & \\
Marital status & & \\
Single & 0 & \\
Married & 84.8 & \\
Widowed & 15.2 & \\
Educational level & & \\
No formal education & 40.6 & \\
Primary education & 29.8 & \\
Secondary education & 22.2 & \\
Tertiary education & 7.0 & \\
Tenancy in Tiv land (Years) & & \\
$21-30$ & 1.6 & \\
$31-40$ & 9.5 & \\
$41-50$ & 8.9 & \\
$51-60$ & 44.1 & \\
$61-70$ & 34.0 & \\
Above 70 years & 1.9 & \\
Household size (persons) & & \\
$1-7$ & 63.5 & \\
$8-14$ & 30.2 & \\
$15-21$ & 5.1 & \\
$22-28$ & 1.2 & \\
Years of farming experience & & \\
$21-30$ & 26.5 & \\
$31-40$ & 49.2 & \\
$41-50$ & 19.5 & \\
$51-60$ & 4.8 & \\
\hline
\end{tabular}

\section{Colonial Influence on Tiv Farming Technologies}

Table 2 shows a number of technologies that were used by the farmers in colonial and post-colonial periods. Specifically, mean distributions show that in the colonial period such technologies as continued application of organic fertilizer $(\bar{x}=2.72)$; pit compositing $(\bar{x}=2.51)$; yam capping $(\bar{x}=2.41)$, inter cropping $(\bar{x}=2.41)$; crop mixture on one plot of land $(\bar{x}=2.40)$ among others were very frequently used by farmers. There was increased frequency of yam intercrops $(\bar{x}=2.65)$; yam based crop mixtures $(\bar{x}=2.64)$; application of inorganic fertilizers $(\bar{x}=2.57)$; yam capping $(\bar{x}=2.53)$; use of pest/disease/weed tolerant 
Creative Commons User License: CC BY-NC-ND

Abstracted by: EBSCOhost, Electronic Journals Service (EJS),

Google Scholar, Journal Seek, Scientific Commons,

Food and Agricultural Organization (FAO), CABI and Scopus

http://eoi.citefactor.org/10.11226/v23i1
Journal of Agricultural Extension

Vol. 23 (1) January, 2019

ISSN(e): 24086851; ISSN(Print); 1119944X

http://journal.aesonnigeria.org

http://www.ajol.info/index.php/iae

Email: editorinchief@aesonnigeria.org

crops $(\bar{x}=2.46)$ and use of yam setts $(\bar{x}=2.44)$ in the post-colonial period. Some technologies that were not very frequently used in the colonial period but very frequently used in the post-colonial period were: use of improved crop varieties $(\bar{x}=2.71)$, use of pesticides $(\bar{x}=2.69)$, use of herbicides $(\bar{x}=2.67)$, use of processing machine $(\bar{x}=2.59)$ among others. These increase in the frequency of use could be largely as a result of colonial influence.

Increased frequency of use of modern or improved technologies were remarkably observed in the postcolonial period despite continued use of some traditional practices. This was due to various reasons ranging from colonialism, need for labour enhancement, need for increased sizes of farm, to increased education of farmers. The fact that such technologies like intercropping and crop mixtures were persistently used in the post-colonial period may be attributed to shortage of land due to increased population which is one of the changes observed, which this practice may be a strategy for surviving the situation. Agricultural techniques, technologies and cropping system needed to be used in relation to historical, ecological and socio-economic contexts of the farmers. With this, the strategies of the farmers are regarded as major repository of skills, and only practices that are considered safe, convenient and compatible with the farmers' farming system persist even after introduction of new practices and technologies over a period of time, since time is a determinant of change (Adedeji, Tiku, Sanusi and Waziri-Ugwu, 2017).

Some traditional practices that have been persistently used in post-colonial period included: use of pest/disease/weed tolerant crops $(\bar{x}=2.46)$, neem liquid/powder for pest control $(\bar{x}=2.00)$ and spraying of wood ash on vegetable to scare insects $(\bar{x}=2.19)$. These traditional innovations/technologies are referred to as organic inputs which are safe pest/disease control measures taken by the farmers and are preferred now due to their health safety implication. Allahyari, Ghavami, Masuleh, Michailidis and Stefanos (2016), asserts that integrating natural process and natural enemies of pest into food production processes through minimizing the use of renewable inputs (pesticides and fertilizers) which are climate friendlier, which damage the environment or harm the health of the farmers and consumers, should be the concern of all stakeholders in agriculture.

The introduction of fertilizers and its frequent use, despite its destructive effect on the environment, may be blamed as being responsible for the low frequency of use of some traditional practices and innovations which are considered safe in the post-colonial period; but due to its influence, acceptability, improvement of soil fertility and enhancement of bumper harvest, farmers insist on its frequent use. Subsidies on fertilizer provided through vouchers may stimulate farmers' demand for nonsubsidized fertilizer, potentially crowdingin the private fertilizer sector (Liverpool-Tasie 2012) leading to more use and demand for fertilizer use. The implication is that a new form of agriculture that should be conscious of when and where to use organic and inorganic inputs needs to be developed through. 
Creative Commons User License: CC BY-NC-ND

Abstracted by: EBSCOhost, Electronic Journals Service (EJS),

Google Scholar, Journal Seek, Scientific Commons,

Food and Agricultural Organization (FAO), CABI and Scopus

http://eoi.citefactor.org/10.11226/v23i1
Journal of Agricultural Extension

Vol. 23 (1) January, 2019

ISSN(e): 24086851; ISSN(Print); 1119944X

http://journal.aesonnigeria.org

http://www.ajol.info/index.php/jae

Email: editorinchief@aesonnigeria.org

Despite the frequency of use of traditional technologies/practices alongside

Table 2: Differences Farming Technologies During Colonial and Post-Colonial Era

\begin{tabular}{|c|c|c|c|c|c|}
\hline \multirow{2}{*}{ Technologies } & \multicolumn{2}{|l|}{ Colonial } & \multicolumn{2}{|c|}{ Post- Colonial } & \multirow[t]{2}{*}{ t-value } \\
\hline & Mean & S. D. & Mean & S. D. & \\
\hline Application of inorganic fertilizer & $2.26^{*}$ & 0.64 & $2.57^{\star}$ & 0.50 & $-6.62^{* *}$ \\
\hline Continued application of organic fertilizer & $2.72^{*}$ & 0.46 & 1.87 & 0.53 & $-21.34^{* *}$ \\
\hline Use of improved crop varieties & 1.33 & 0.57 & $2.71^{*}$ & 0.48 & $-7.87^{* *}$ \\
\hline Use of optimum plant population on farm & 1.81 & 0.65 & $2.09^{*}$ & 0.61 & $-5.45^{\star *}$ \\
\hline Use of herbicides & 1.38 & 0.59 & $2.67^{*}$ & 0.48 & $-30.25^{\star *}$ \\
\hline Use of pesticides & 1.82 & 0.72 & $2.69^{*}$ & 0.48 & $-17.74^{\star \star}$ \\
\hline Use of alternate row cropping pattern & 1.75 & 0.68 & $2.05^{*}$ & 0.51 & $-4.89^{* *}$ \\
\hline Agro-forestry practice & $2.12^{*}$ & 0.74 & 1.66 & 0.67 & $6.47^{* *}$ \\
\hline Use of pest/disease/weed tolerant crop & $2.04^{*}$ & 0.68 & $2.46^{*}$ & 0.57 & $-6.54^{\star \star}$ \\
\hline Neem liquid/powder as insecticide & $2.15^{\star}$ & 0.77 & $2.00^{*}$ & 0.73 & 1.83 \\
\hline Tobacco powder as insecticide & $2.19^{*}$ & 0.88 & 1.44 & 0.67 & $9.20^{* *}$ \\
\hline Mucuna planting as cover cropping & $2.05^{\star}$ & 0.74 & 1.89 & 0.79 & $2.21^{* *}$ \\
\hline Pit composition for soil fertility maintenance & $2.51^{*}$ & 0.62 & $2.32^{*}$ & 0.64 & $3.42^{\star *}$ \\
\hline Use of processing machine & 1.57 & 0.59 & $2.59^{*}$ & 0.49 & $-18.34^{* *}$ \\
\hline Dry season farming & $2.33^{*}$ & 0.59 & $2.33^{*}$ & 0.49 & 0.07 \\
\hline Use of tractor for cultivation & 1.18 & 0.41 & $2.00^{*}$ & 0.63 & $-19.12^{* *}$ \\
\hline Planting heat resistant crops & 1.59 & 0.69 & 1.80 & 0.60 & $-4.14^{* *}$ \\
\hline Intercropping & $2.41^{*}$ & 0.61 & $2.65^{*}$ & 0.52 & $-5.33^{* *}$ \\
\hline $\begin{array}{l}\text { Broadcasting rice on cultivated land to pave way for other } \\
\text { activities }\end{array}$ & 1.87 & 0.80 & $2.05^{*}$ & 0.75 & $-3.01^{* *}$ \\
\hline Broadcasting rice on land that is sprayed with chemicals & 1.92 & 0.79 & $2.01^{*}$ & 0.73 & -1.47 \\
\hline Planting legumes on early cultivated yam moulds & $2.14^{*}$ & 0.63 & 1.90 & 0.66 & $4.53^{* *}$ \\
\hline Killing trees on farms without felling them & $2.28^{*}$ & 0.77 & 1.51 & 0.60 & $-13.39^{* *}$ \\
\hline Raising nursery for vegetables during dry season & 1.97 & 0.69 & $2.12^{*}$ & 0.63 & $-2.88^{* *}$ \\
\hline Use of yam setts & $2.30^{*}$ & 0.61 & 2.448 & 0.62 & $-2.79^{\star *}$ \\
\hline Yam capping between Aug and Oct & $2.41^{*}$ & 0.66 & $2.53^{*}$ & 0.54 & $-2.54^{* *}$ \\
\hline Sprinkling wood ash on vegetable to scare insects & $2.35^{*}$ & 0.61 & $2.19^{*}$ & 0.60 & $3.24^{\star *}$ \\
\hline Spraying with chemicals & 1.26 & 0.59 & $2.40^{*}$ & 0.60 & $-23.66^{\star *}$ \\
\hline Planting cover crops & 1.95 & 0.68 & $2.16^{*}$ & 0.72 & $-3.89^{* *}$ \\
\hline Prunning crops for more yield & 1.67 & 0.69 & 1.88 & 0.64 & $-3.82^{* *}$ \\
\hline
\end{tabular}

${ }^{\star \star} P \leq \mathbf{0 . 0 5} \quad{ }^{*}$ Mean values above cut off

improved/modern technologies/practices in the post-colonial period, a T- test to compare

the significance of the change between the frequency of use of technologies in the periods shows that there was significant difference in the use of the innovation/technologies at $\mathrm{P} \leq$ 0.05 except for neem liquid/powder for as insecticide, dry season farming and broadcasting rice on land that is sprayed with chemicals. The implication is that irrespective of the conflict and resistance the farmers may have had or put up against external contacts/intervention programmes, they have already caused a lot of changes in the use of technologies in agriculture among the Tiv and even in their social system. It is believed that 
Creative Commons User License: CC BY-NC-ND

Abstracted by: EBSCOhost, Electronic Journals Service (EJS),

Google Scholar, Journal Seek, Scientific Commons,

Food and Agricultural Organization (FAO), CABI and Scopus

http://eoi.citefactor.org/10.11226/v23i1
Journal of Agricultural Extension

Vol. 23 (1) January, 2019

ISSN(e): 24086851; ISSN(Print); 1119944X

http://journal.aesonnigeria.org

http://www.ajol.info/index.php/jae

Email: editorinchief@aesonnigeria.org

changes in socio-cultural and traditional practice of societies also reflects in the changes in agricultural practices and it usually take place over a long period of time (Mbagwe, 2015).

\section{Farm Tools Used among the Tiv in the Colonial and Post-Colonial Periods and Reasons for Changes}

More traditional farm tools were used in the colonial period compared to modern and improved technological tools in the post-colonial period (Table 3). However, by postcolonial period more modern/improved technological tools such as wheelbarrows (95.2\% and $+2620.0 \%$ change), pushing truck (Amaliki) $(79.4 \%$ and $+260.9 \%$ change), tractors $(97.5 \%$ and $+4331.8 \%$ change), drying sheets (per) $(83.5 \%$ and $+449.3 \%$ change) and processing machines ( $88.2 \%$ and $+1256.9 \%$ change) were used. Traditional tools were comparatively still highly used in the post-colonial period but percentage change analysis revealed comparative reduced usage of these technologies in the post-colonial period which were: wooden handle and iron base hoe (90\% and $7.8 \%$ change), small wooden handle iron base hoe (Abya) $(94.8 \%$ and $-0.4 \%$ change), basket(ikyese) $(60 \%$ and $-37.5 \%$ change), and axe (ljembe) $(62.9 \%$ and $-35.2 \%$ change).

Changes in the use of tools between the periods may be attributed to the need for work enhancement and for technological advancement. It may also be due to involvement of more educated farmers in agriculture during the post-colonial period compared to the colonial period. This, coupled with access to extension services, could have facilitated the use of modern technological tools.

The finding implies that due to the fact that most traditional farm tools were outdated and could not cope with the volume of work done by the farmers in the post-colonial period to enhance their work volume; those tools were dropped for newly improvised ones. Where the old farm tools were still serving their purposes, the farmers still continued their use even in the post-colonial period. Similarly, those technological advanced tools which were not compatible with their work volume were not used, while those that were compatible were used. Perception of farmers towards a new technology is a key precondition for adoption to occur. From the review, the determinant of agricultural technology adoption does not always have the same effect on adoption rather the effect varies depending on the type of technology being introduced (Mwangi1 and Kariuki, 2015). 
Creative Commons User License: CC BY-NC-ND

Abstracted by: EBSCOhost, Electronic Journals Service (EJS),

Google Scholar, Journal Seek, Scientific Commons,

Food and Agricultural Organization (FAO), CABI and Scopus

http://eoi.citefactor.org/10.11226/v23i1
Journal of Agricultural Extension

Vol. 23 (1) January, 2019

ISSN(e): 24086851; ISSN(Print); 1119944X

http://journal.aesonnigeria.org

http://www.ajol.info/index.php/iae

Email: editorinchief@aesonnigeria.org

Table 3: Farm tools used among the Tiv in the colonial and post-colonial periods

\begin{tabular}{llll}
\hline Tools & Colonial & $\begin{array}{l}\text { Post- } \\
\text { colonial }\end{array}$ & $\begin{array}{l}\text { Percentage } \\
\text { change }\end{array}$ \\
\hline Wooden hoes & 98.4 & 4.1 & -95.8 \\
Iron base hoes & 97.8 & 90 & -7.9 \\
Iron-tip digging stick & 100 & 1 & -99 \\
Small weeding hoe & 95.2 & 94.8 & -0.4 \\
Head pan/basin & 98.4 & 41.6 & -57.7 \\
Calabash (kapu,kucha) & 100 & 0.6 & -99.4 \\
Wheel barrow & 3.5 & 95.2 & 2620 \\
Pushing truck (AmalikI) & 22 & 79.4 & 260.9 \\
Planting stick & 100 & 0.6 & -99.4 \\
Axe (Ijembe) & 97.1 & 62.9 & -35.2 \\
Cutlass (Ishom) & 86 & 13 & -84.9 \\
Tractor and accessories & 2.2 & 97.5 & 4331.8 \\
Drying sheet (Per) & 15.2 & 83.5 & 449.3 \\
Winnowing tray $($ Tser) & 98.1 & 63 & -35.8 \\
Basket (Ikyese) & 97.5 & 60 & -38.5 \\
Processing machine & 6.5 & 88.2 & 1256.9 \\
\hline
\end{tabular}

\section{Sources of Planting Materials among Tiv Households}

Data in Table 4 shows that greater $(49.2 \%)$ proportion of the respondents acquired yam species from neighbors, 36.3 percent from the wild forest in the colonial period, while in the post-colonial period, the majority (58.2\%) acquired seed yam from the open market, 35.8 percent from neighbors and 5.4 percent from ADPs.

Percentage change analysis shows that forest (-100\% change) and neighbours (-27.2\% change) as sources of acquiring planting materials were abandoned and reduced respectively in the post-colonial period, while market and ADP (BNARDA) had replaced them. The fact that the majority of the respondents acquire seed yams from the market may be attributed to the changing economic situation where money was now the only medium of exchange and virtually everything was now an article for sale. This could be as a result of the policies initiated post-colonial era as posited by Frankema, Green, \& Hillbom (2014) that, Colonial authorities recognized the potential of African entrepreneurship and lifted restrictions on African producers, but the speed and depth of these institutional reforms depended largely on the comparative strength of the settler farmers lobby and gain freedom to engage in both input and output marketing.

Respondents did not know much about cassava in the colonial period but the majority $(71.7 \%)$ of the respondents acquired cassava stock from the market, 50.4 percent from neighbors and 20.9 percent from ADPs in the post-colonial period. This indicates that respondents acquire planting materials from informal sources rather than the official source (the ADPs). This may be attributed to the fact that respondents were so much dependent on interpersonal channels of social relations such as family/community meetings where contact with neighbours was common and communication enhanced as result of common 
social actions in relation to a "cause". It is believed that interpersonal sources can serve as good platform for the exchange of innovations since changes in the way people do things is largely from interaction with others.

The majority (56\%) of the respondent acquired sorghum through neighbours in the colonial period but in the post-colonial period, a larger proportion (36.4\%) acquired sorghum from the market and $26.2 \%$ from neighbours indicating that neighbours $(-53.2 \%$ change) as a source of acquiring planting material was becoming unpopular. This could imply that sorghum planting materials has not yet been very commercialised to be sold in markets which might be as a result of the level of development of research in the introduction of new varieties of sorghum.

While soyabean (5\%) was mainly acquired from the agro service centres/ ADPs in the colonial period, a greater proportion (35.8\%) acquired soybean from the market in the postcolonial period indicating 446 percent change between the periods. The fact that respondent acquired soybean from only agro services centers/ADPs in the colonial period indicates that it was a new crop introduced by the colonial government. The implication of the above results was that; market has become an important major source of acquiring planting material in the post-colonial period. This agrees with Agber (2002) in Ivande 2014, who observes that monetization of the capitalist economies penetrated Tiv land and through this penetration, production of goods and services were redirected to the output commodities that could be exchanged in the market. Generally, it was observed that market as a source of acquisition of different commodities including planting materials had overtaken all other sources of acquisition in the area. This implies that special attention needs to be paid to the marketing system of the people in such a way that it should benefit both the sellers and buyers to the extent that production may be continuously motivated.

FGD (2012) revealed that all articles can be traded in the market in the area but constraints to market system in the area included unregulated measures for selling products which are exploitative of farmers. Oversized measures are used in buying products from the farmers and standard sizes were used in selling to consumers including farmers when they run out of the supply during the hunger months. All these could be averted with well organised farmers' association/ organizations. United Nation (2016), was of the view that farmerbased organizations facilitate member access to output markets and assist farmers to procure inputs such as seeds and fertilizers in bulk. They also provide farmers with better access to finance and extension services, which in turn reduces their production costs while increasing their productivity, thereby increasing their profit margins and incomes by aiding marketing access and informations. Rice (8.6\%) was also acquired from neighbours in the colonial period but indicated $+351.2 \%$ change in the post-colonial period. These changes could be attributable to level of developments and popularity rice as a commodity have received since independence as it has become in higher demand and several research has been ongoing on it. 
Creative Commons User License: CC BY-NC-ND

Abstracted by: EBSCOhost, Electronic Journals Service (EJS),

Google Scholar, Journal Seek, Scientific Commons,

Food and Agricultural Organization (FAO), CABI and Scopus

http://eoi.citefactor.org/10.11226/v23i1
Journal of Agricultural Extension

Vol. 23 (1) January, 2019

ISSN(e): 24086851; ISSN(Print); 1119944X

http://journal.aesonnigeria.org

http://www.ajol.info/index.php/iae

Email: editorinchief@aesonnigeria.org

Table 4: Sources of planting materials in the colonial and post-colonial era

\begin{tabular}{|c|c|c|c|c|c|c|c|c|}
\hline & \multicolumn{3}{|c|}{ Colonial } & & \multicolumn{3}{|c|}{ Post-colonial } & \multirow[b]{2}{*}{ BNARDA } \\
\hline & $\begin{array}{l}\text { Fores } \\
t\end{array}$ & Market & $\begin{array}{l}\text { Neighbou } \\
r\end{array}$ & BNARDA & Forest & Market & Neighbour & \\
\hline Yam & 36.3 & 0 & 49.2 & 0 & $0(-100)$ & 58.2 & $\begin{array}{l}35.8 \\
27.2)\end{array}$ & 5.4 \\
\hline Cassava & 0 & 0 & 0 & 0 & $0(0)$ & 71.7 & 50.4 & 20.9 \\
\hline $\begin{array}{l}\text { Sorghu } \\
\text { m }\end{array}$ & 13.0 & 0 & 56.0 & 0 & $0(-100)$ & 36.4 & $\begin{array}{l}26.2 \\
53.2)\end{array}$ & 0 \\
\hline Soybean & 0 & 0 & 0 & 5 & $0(0)$ & 35.8 & 20.8 & $27.3(446)$ \\
\hline Rice & 0 & 0 & 8.6 & 0 & $0(0)$ & 47.3 & $\begin{array}{l}38.8 \\
(351.2)\end{array}$ & 22.6 \\
\hline
\end{tabular}

\section{Figures in parenthesis are \%change}

\section{Conclusion and Recommendation}

There have been significant changes in the frequency of use of different technologies available to farmers. These changes were seen to be more in use of modern technologies and practices, which were more practiced post-colonial period. This is in spite of the continued and persistent use of some traditional technologies and practices. Market as a source of acquisition of different commodities including planting materials had overtaken all other sources of acquisition in the area.

Funded intervention programmes that provides the use of innovations and better way of farm production should be encouraged by various states by providing required condition to participate. This is because when innovations show comparative advantages farmers adopt them and drop old practices.

Interventions should increase in the aspect of commodity market as well as market infrastructure both by government and development agencies, this because the market is increasingly becoming key sources of farming input and not just places for selling off farm produce.

Research institutes should also build good linkages with various marketing agencies and marketing organisation to enable farmers get quality and appropriate farm inputs from market places. This could also entail increased surveillance and monitoring of farming inputs at market place.

\section{References}

Adedeji, I. A, Tiku, N. E Sanusi S.O and Waziri-Ugwu P. R (2017). Trend analysis of crop productivity growth in Nigeria (1961-2014). Agroeconomia Croatica 7:2017 (1) 1424

Allahyari M S, Ghavami S, Masuleh Z.D, Michailidis A and Stefanos A. N (2016). Understanding Farmers' Perceptions and Adaptations to Precipitation and Temperature Variability: Evidence from Northern Iran. Climate 2016, 4, 58

Benoît, G. (2015). Technological Change What do Technology and Change stand for? Project on the Intellectual History of Innovation Working Paper No. 242015 
Creative Commons User License: CC BY-NC-ND

Abstracted by: EBSCOhost, Electronic Journals Service (EJS),

Google Scholar, Journal Seek, Scientific Commons,

Food and Agricultural Organization (FAO), CABI and Scopus

http://eoi.citefactor.org/10.11226/v23i1
Journal of Agricultural Extension

Vol. 23 (1) January, 2019

ISSN(e): 24086851; ISSN(Print); 1119944X

http://journal.aesonnigeria.org

http://www.ajol.info/index.php/iae

Email: editorinchief@aesonnigeria.org

Benue State Agricultural and Rural Development Authority (BNARDA) (2004). Impact study of Roots and Tubers Expansion Programme (RTEP) in Benue State Nigeria. PME, BNARDA, Makurdi. Nigeria.

Frankema, E. Green, E. \& Hillbom, E (2014). Success and Failure of European Settler farming in Colonial Africa. (Africa Economic History Network Working Paper Series; No. 16). African economic History network.

Ivande P.D. (2014). Assessment of social and technological change in agriculture among the Tiv, in Nigeria, (Unpublished Ph. D. Thesis) submitted to the Department of Agricultural Extension, University of Nigeria, Lagos or where

Liverpool-Tasie, S. (2012). Targeted subsidies and private market participation: An assessment of fertilizer demand in Nigeria IFPRI Discussion Paper 01194. Washington DC: IFPRI.

Mbakwe P.U. (2015). The impact of colonial rule on the agricultural economy of Mbaise, Imo State, 1500-1960. African Journal of History and Culture. Vol. 7(6), pp. 133-140, June,

Ministry of Women Affairs and Social Development Benue State (MOWASDBS) (2008). Gender barriers to utilization of family planning commodities and services; United Nations Population Fund Supported Programme. Ministry of Women Affairs and Social Development ,Benue State (MOWASDBS), Makurdi, Nigeria.

Mondal P. (2015). Top 5 Theories of Social Change - Explained. Published online and available $\quad$ http://www.yourarticlelibrary.com/sociology/top-5-theories-of-socialchange-explained/35124/

Mwangi M. and Kariuki S. (2015). Factors Determining Adoption of New Agricultural Technology by Smallholder Farmers in Developing Countries. Journal of Economics and Sustainable Development. Vol. 6 (5), pp. 208-216

Soni, S. (2012). Lifelong Learning - Education and Training. FIG Working Week 2012 Knowing to manage the territory, protect the environment, evaluate the cultural heritage Rome, Italy, 6-10 May.

United Nations (2015). World population prospects: the 2015 revision, DVD edition: United Nations, Department of Economic and Social Affairs, Population Division.

United Nations (2016). Agricultural commodity value chains: The effects of market concentration on farmers and producing countries-the case of cocoa. Trade and Development Board Sixty-third session Geneva, 5-9 December 2016 Item 2 of the provisional agenda. 